\title{
Physico-Chemistry of Elechi Creek in the Upper Bonny Estuary, Rivers State, Nigeria
}

\author{
Amauche Sabastine Ngah"1, Solomon Braide ${ }^{2}$, Collins Chiadi Dike1 \\ ${ }^{1}$ Institute of Geosciences and Space Technology, Rivers State University of Science and Technology, Port Harcourt, Nigeria \\ ${ }^{2}$ Institute of Pollution Studies, Rivers State University of Science and Technology, Port Harcourt, Nigeria \\ Email:ngahsab@yahoo.com
}

How to cite this paper: Ngah, A.S., Braide, S. and Dike, C.C. (2017) Physico-Chemistry of Elechi Creek in the Upper Bonny Estuary, Rivers State, Nigeria. Journal of Geoscience and Environment Protection, 5, 181-197.

https://doi.org/10.4236/gep.2017.58015

Received: March 10, 2017

Accepted: August 4, 2017

Published: August 7, 2017

Copyright $\odot 2017$ by authors and Scientific Research Publishing Inc. This work is licensed under the Creative Commons Attribution International License (CC BY 4.0).

http://creativecommons.org/licenses/by/4.0/

\begin{abstract}
The physico-chemistry of tidal Elechi Creek in the upper Bonny Estuary was investigated to assess the toxicity of the water body as this could have adverse effects on the native organisms that form part of the ecosystem and to evaluate the extent and magnitude of petroleum hydrocarbon and heavy metal concentration in the water body. Standard field procedures were adopted in sample collection while laboratory analysis was carried out also following standard methods. Parameters measured include $\mathrm{pH}$, temperature, dissolved oxygen (DO), biological oxygen demand (BOD), electrical conductivity, salinity and total dissolved solids (TDS). Heavy metals namely Copper $(\mathrm{Cu})$, Lead $(\mathrm{Pb})$, Zinc $(\mathrm{Zn})$, nitrate $\left(\mathrm{NO}_{3}\right)$, sulphate $\left(\mathrm{SO}_{4}\right)$, Ammonia $\left(\mathrm{NH}_{4}\right)$, and Total Hydrocarbon Concentration (THC) in the surface water body were also determined on samples collected from five (5) sampling stations spread along the creek in both dry and wet seasons. The results showed that the surface water body is oligohaline with low acidity, $\mathrm{pH}$ values ranging from 6.2 to 7.6 . Temperature varies from $27^{\circ} \mathrm{C}$ to $30^{\circ} \mathrm{C}$. Dissolved Oxygen (DO) concentration ranges from 2.9 to $7.5 \mathrm{mg} / \mathrm{l}$ which is adequate for aquatic organism with Biological Oxygen Demand (BOD) values varying from 0.45 to $7.0 \mathrm{mg} / \mathrm{l}$. The values of total dissolved solids (TDS) vary from $11,700 \mathrm{mg} / \mathrm{l}$ to $26,250 \mathrm{mg} / \mathrm{l}$ with the highest mean value obtained at the study station located downstream. The mean nutrient concentration showed that the study area is not eutropic. Anthropogenic activities were very high at the sites throughout the period of the study and may have resulted in the stress conditions of the area. Pollution trend along the study stations showed that no one station is unpolluted. The study recommends the introduction of enforceable and stringent waste management plans to highlight and discourage direct discharge of untreated waste and storm water runoff into an aquatic environment.
\end{abstract}




\section{Keywords}

Physico-Chemistry, Elechi Creek, Rivers State, Nigeria

\section{Introduction}

Water is an indispensable natural resource without which there would have been no life on earth. The importance of water to man cannot be over emphasized. Man can survive longer without food than without water. Water is freely available through rainfall and other components of the hydrologic cycle. Until recently, man has tended to take this abundant natural resource for granted [1]. The increased concern on the rapid ecological changes in the natural environment has provided major challenges to the scientific community [2]. The emerging empirical facts have shown the susceptibility and sensitivity of ecological assemblages which have been ignored especially the open water body dwelling communities in brackish and other waters of Niger Delta. The first sign of pollution in an aquatic system includes toxic algal blooms and associated deoxygenation of surface water.

Studies have been undertaken on macrofauna in Bonny and other Niger Delta environment [3] [4] [5] [6]. These studies have provided information on the physicochemistry, Benthos; [7] [8] and [9] on benthos, [10] on intertidal macrofauna while [11] on fisheries of Bonny estuary. A good surface water quality has dissolved oxygen (DO) values exceeding $2 \mathrm{mg} / \mathrm{l}$ [12]. This fact underpins the necessity of a thorough evaluation of the physicochemistry of Elechi Creek, a busy and actively tidal creek in Port Harcourt.

The study is on the creeks stretching from Abonnema wharf to Mgbouosimini waterfront. It attempts to establish possible effects of anthropogenic activities on the physicochemical parameters of the creek and provide mitigating measures with a view to preserving the environment. It also tries to generate an index using developed water quality index from observed temporal and spatial variation in some physicochemical parameters in the area.

Assessment of water is not only for suitability for human consumption but also in relation to its agricultural, industrial, recreational, commercial uses and, from environmental point of view, its ability to sustain aquatic life. Water quality monitoring is therefore a fundamental tool in the management of freshwater resources. To achieve the aim of this study, the following evaluations were made: water quality, extent and magnitude of petroleum hydrocarbon and heavy metal concentration, relationship between the physicochemical characteristics and the aim of identifying zones within the study area that could show acute toxicity to native organisms.

\section{Description of the Study Area}

The study was conducted in a brackish wetland of Bonny estuary between Ab- 
onnema wharf and Mgboushimini. The creek lies Southwest of Port Harcourt between longitude $04^{\circ} 46^{\prime} 743^{\prime \prime} \mathrm{N}$ and $007^{\circ} 00^{\prime} 557^{\prime \prime} \mathrm{E} ; 04^{\circ} 48^{\prime} 217^{\prime \prime} \mathrm{N}$ and $006^{\circ} 48^{\prime} 989^{\prime \prime} \mathrm{E}$ (Figure 1). It is protected from strong wave actions prevalent in the main Bonny River Channel and the current flow velocity is minimal (about $3 \mathrm{~m} / \mathrm{s}$ ). Tidal amplitude is about $1.20 \mathrm{~m}$. A detailed description of the hydrology of the system is contained elsewhere [13].

The area enjoys tropical equatorial climate. Two main seasons are dominant namely, the rainy season (March to November) and the dry season (December to February) Annual rainfall in the area is about $2405.20 \mathrm{~mm}$ (Gobo, 1988). Annual mean air temperature is $29.7^{\circ} \mathrm{C}$ with the highest monthly mean temperature at $31.3^{\circ} \mathrm{C}$ (in August), and the lowest monthly mean temperature at $27.5^{\circ} \mathrm{C}$ (in January). The surface seawater temperature varies between $25.9^{\circ} \mathrm{C}$ and $30.6^{\circ} \mathrm{C}$, and the salinity of the surface water varies between $8 \%$ and $20 \%$. The tidal variations range between $0.43 \mathrm{~m}$ and $1.67 \mathrm{~m}$ with a mean tidal variation of $0.90 \mathrm{~m}$. The water current flows in directions, flooding (inundation) during high tide and receding at low tide regimes. The mud (sediment) had a dark appearance with hydrogen sulphide as the major byproduct of sulphate reducing bacteria. The soil type is mainly clay (Chikoko). The intertidal flat consists of moderately sorted sand to silty clay with patches of hard "Chikoko" sediment types [10].

Vegetation in the area is characteristically mangrove, with the dominant types being red mangrove (Rhizophora racemosa), white mangrove (Avicennia africana) and black mangrove (Laguncularia racemosa). The area is also inhabited by other plants (e.g. fern-Achrostichum aureum and grass-Paspalum varginatum). Animals found in the area include (mud skipper Periophthalmus sp., fidder crabs Uca tangeri and Periwinkles). The vegetation of the head water and stream banks are intact, and had been referred to as un-degraded stream systems [14] [15].

\section{Materials and Method}

Five study stations were established along the creek from Abonnema wharf to Mgbousimini, (Figure 1). They include:

1) Abonnema Wharf station (ABWS $1 \& 2$ ). Activities here are mostly boat transportation and sale of petroleum products.

2) Elechi Beach station (EBS $1 \& 2$ ). Activities here include lifting of petroleum products and waste disposal.

3) AGIP Jetty Station (AJS 1 \& 2). Activities include ship transportation and runoff.

4) Mgboushimini Station (MBS $1 \& 2$ ); influenced by effluent from slaughter, burnt tyres, market and solid waste disposal.

5) Control Station (CS $1 \& 2$ ); characterised by relatively low human activity.

Sample collection was done according to standard procedures. Water samples were collected in both dry season (November-December 2012 and January 2013) and peak wet season (August and September 2013). 


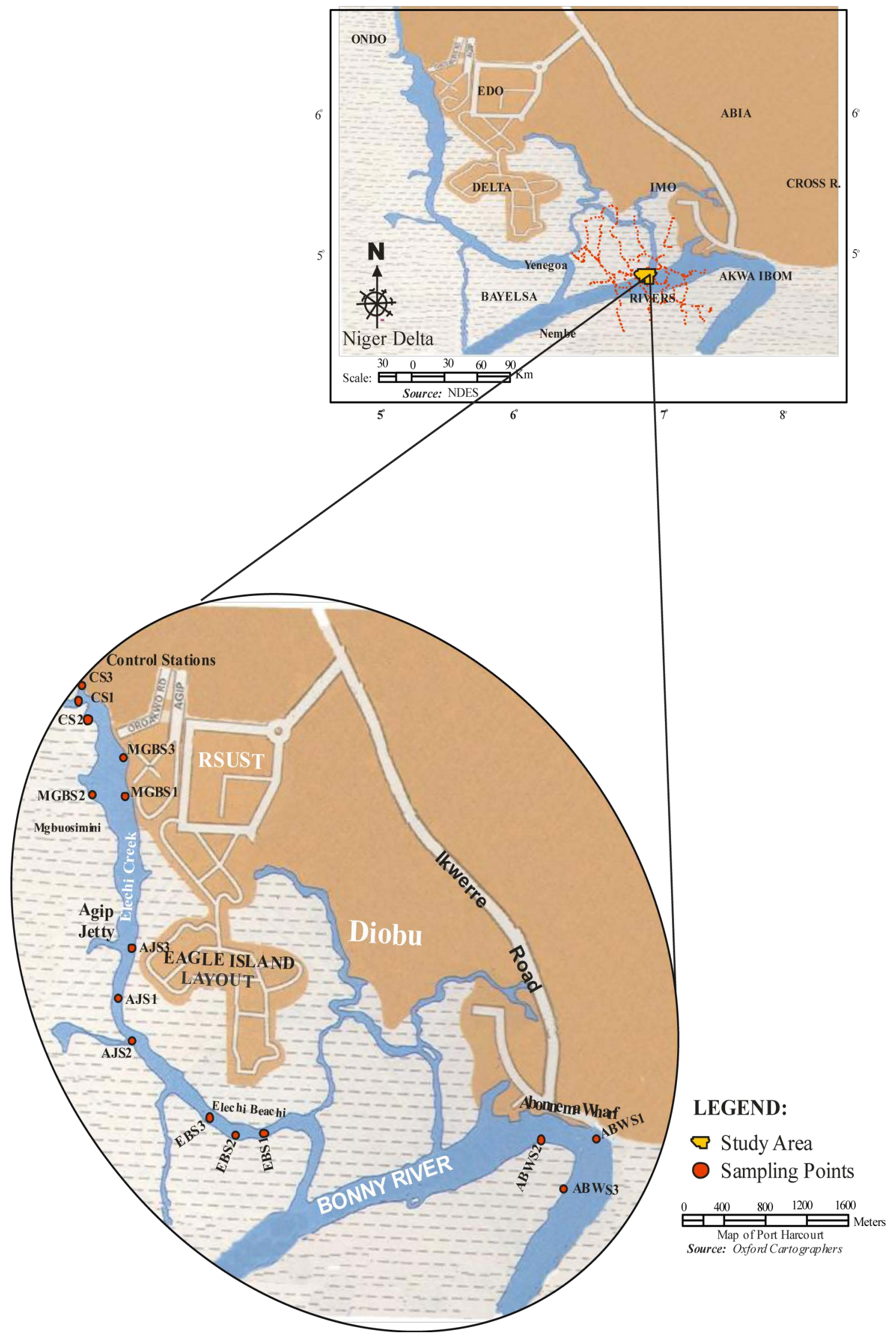

Figure 1. Map of study area. 
Surface water samples were collected on a monthly interval at ebbing tide during the study period. Water samples were taken at about $30 \mathrm{~cm}$ below the water surface by a horizontal water bottle made of polyvinyl chloride.

One sample was collected at each of these locations, two replicate samples from each group stations.

At each sampling station, in situ measurement of unstable parameters such as temperature was made while the elevation and the sampling location were geo-referenced.

The parameters measured are Temperature (in situ), $\mathrm{pH}$, Conductivity, Dissolved Oxygen, Biological Oxygen Demand (BOD), Total Dissolved solid (TDS), Salinity, Total hydrocarbon concentration (THC), and Heavy metals. The samples were taken to the laboratory of the Institute of Pollution Studies, Rivers State University of Science and Technology, Port Harcourt, where the analysis took place following standard analytical procedures.

\section{Results}

\section{Surface Water $\mathrm{pH}$}

The result of the mean surface water $\mathrm{pH}$ of the study area showed that the surface water is weakly acidic to weakly alkaline with values ranging from 6.40 in AJS in dry season to 7.60 in EBS in the wet season. This is expected since in the dry season, there is some fresh water influence in the study area while the alkaline seawater dominates.

The spatial and temporal variation in surface water $\mathrm{pH}$ is presented in the Figure 2.

\section{Surface Water Temperature}

The results of surface water temperature range from $27.6^{\circ} \mathrm{C}$ to $30^{\circ} \mathrm{C}$. The highest temperature was recorded in January, dry season and the lowest value was recorded in August, wet season, Figure 3.

\section{Surface Water Electrical Conductivity (EC)}

The results of mean EC of surface water in the study sites showed that the maximum value was recorded in January, 2013, dry season; as 28,250 $(\mu \mathrm{s} / \mathrm{cm})$ at Abonnema Wharf station (ABWS) site. The minimum value was obtained in September 2013 wet season, as $12,775(\mu \mathrm{s} / \mathrm{cm})$ at Mgboushimini sample sites

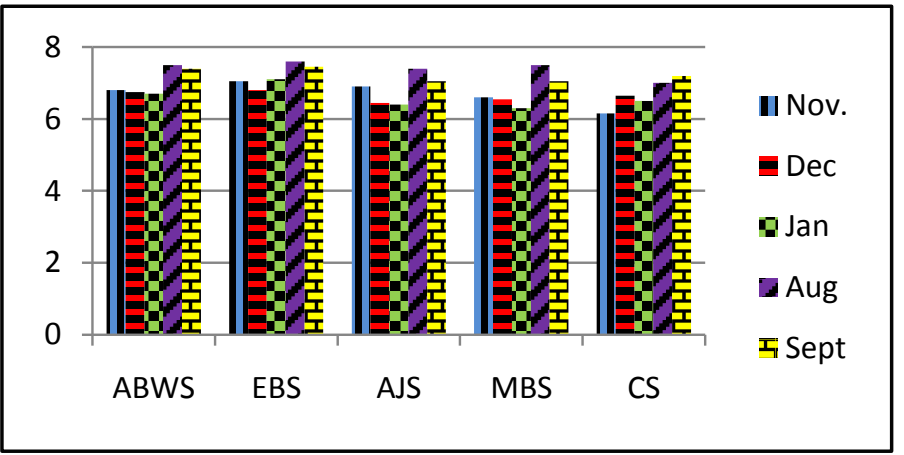

Figure 2. Variation of surface water $\mathrm{pH}$ in the study stations. 
(MBS). The difference between the maximum and the minimum values was $15,475(\mu \mathrm{s} / \mathrm{cm})$. Spatial and temporal variations in the EC are presented in Figure 4.

Considerable spatial and temporal changes in values were observed at the sampling sites throughout the study periods. The temporal change showed a decline in the EC values at MBS sites, but was more pronounced at the ABWS site. Except for the month of December 2012 (dry season), the values obtained at MBS sites showed a continuous decline for the periods of the study.

\section{Surface Water Salinity (\%o)}

The results of the measurements of mean salinity of the surface water shows that the values ranged between $7.00(\%)$ and $17.20(\%) \pm 10.20(\%)$. The variation in the level of salinity is quite high. The highest level of salinity was recorded in August 2013 (wet season), at the Abonnema Wharf study sites as 17.20(\%o), while the least value was recorded in September 2013 (wet season), at MBS study site as 7.00(\%o). On a general note, salinity levels fluctuates. However, higher values were recorded at Abonnema Wharf study site than other sites. Figure 5 shows the variations of the salinity of the sampling sites.

\section{Dissolved Oxygen (DO) concentration of Surface Water Samples}

The results showed that the values of the DO vary between $2.85 \mathrm{mg} / \mathrm{l}$ and 7.50 $\mathrm{mg} / \mathrm{l}$. The minimum value of DO was recorded at Elechi Beach in November 2012 (dry season), while the maximum value was recorded at the MBS site in August 2013 (wet season). The concentration of DO during the periods of

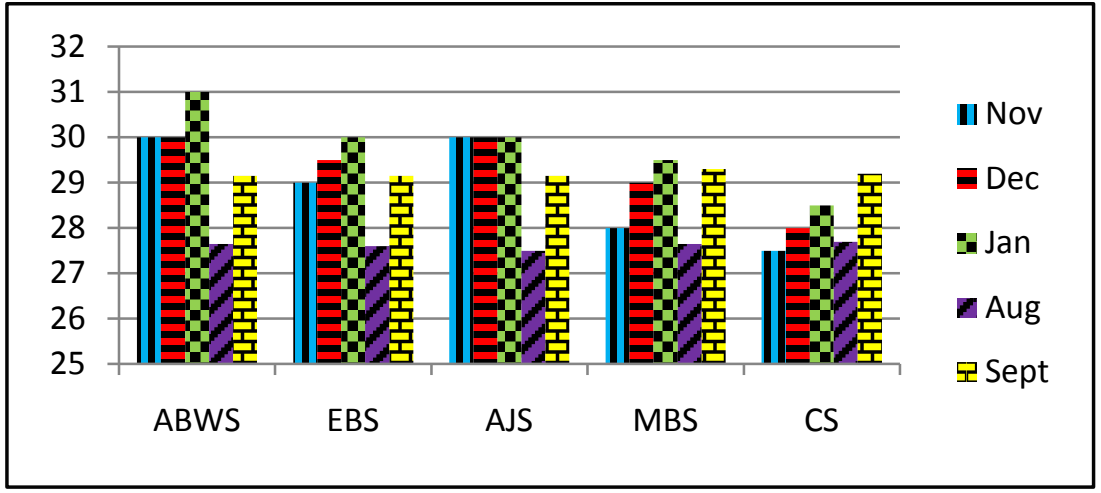

Figure 3. Variations in surface water temperature in the study stations.

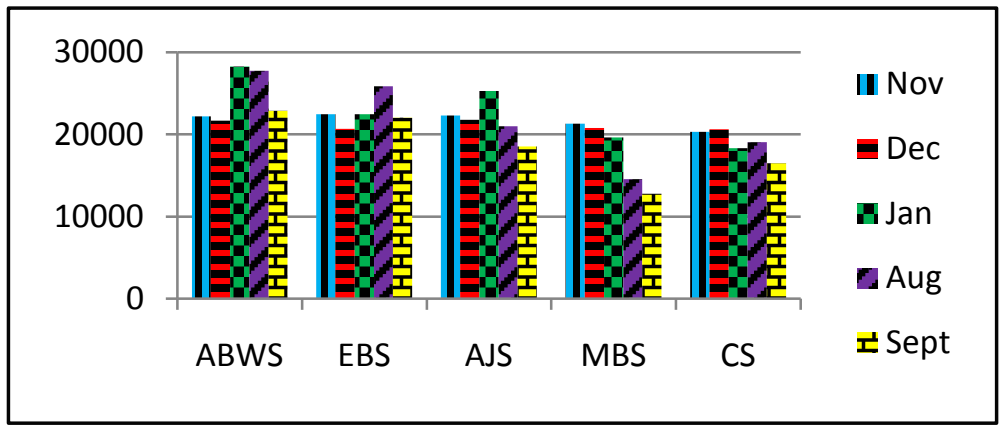

Figure 4. Variations of electrical conductivity in study stations. 
the study did not follow any particular pattern. Figure 6 shows variations in the DO across the study stations.

Biological Oxygen Demand (BOD) of Surface Water of the Sampling Sites

The (BOD) results of the surface water show that the values ranged between 0.45 and $7.50 \mathrm{mg} / \mathrm{l}$ within the periods of the study. The least value was recorded in November 2012 dry season, at ABWS study sites while the highest value was recorded in August 2013 wet season at MBS Study Sites with a value of 7.50 $\mathrm{mg} / \mathrm{l}$. The spatial and temporal variation of mean BOD concentration is presented in the Figure 7.

The results do show some pattern of the distribution of $\mathrm{BOD}_{5}$. Hence, the values increased steadily at the stations.

Total Dissolved Solid (TDS) Concentration of Surface Water in Sampling Sites

Results show that the values ranged between 10,185 and 26,250 (mg/l) within the periods of the study. The least value was recorded in August 2013 wet season, at MBS study sites while the highest value of $26,250 \mathrm{mg} / \mathrm{l}$ was recorded in January 2013 dry season at ABWS which could be attributed to the human activity taking place in the study site. The spatial and temporal variation of mean Total Dissolved Solid (TDS) concentration is presented in the Figure 8.

\section{Concentration of Nitrate $\left(\mathrm{NO}_{3}\right)$ in Surface Water}

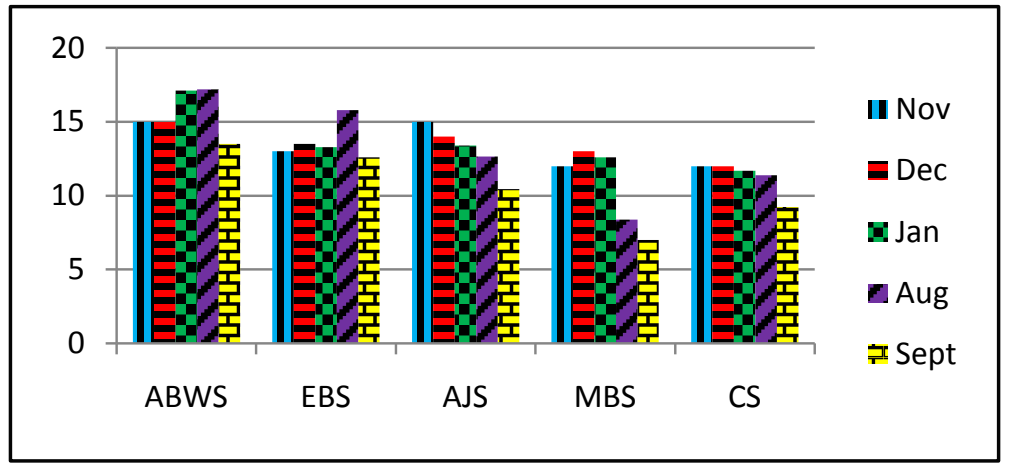

Figure 5. Variation of salinity in surface water in the study stations.

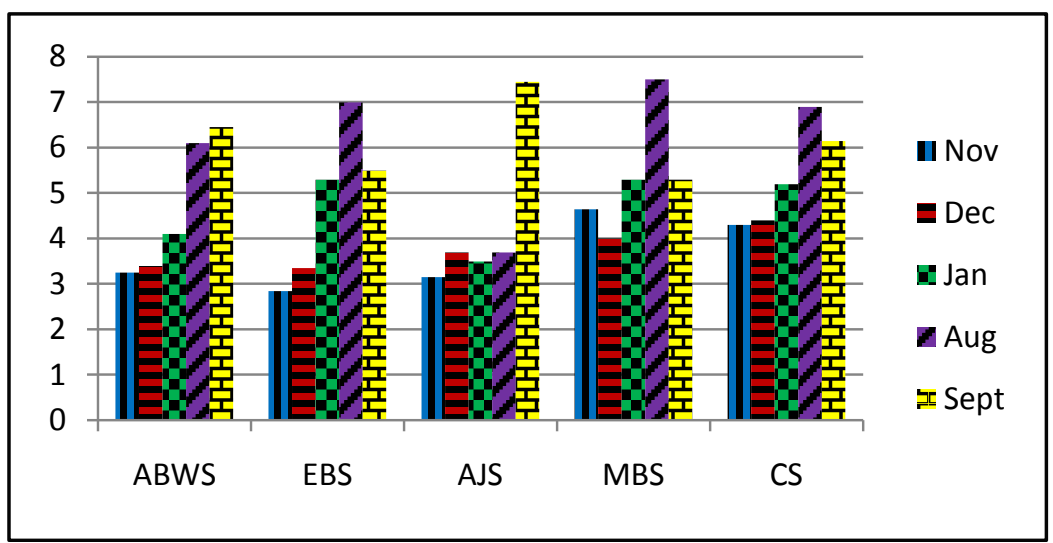

Figure 6. Variation of surface water DO (mg/l) across the study stations. 
The result showed that the Nitrate $(\mathrm{mg} / \mathrm{l})$ concentrations of the surface water ranged between 0.15 and $2.51 \mathrm{mg} / \mathrm{l}$, with a difference of $1.45 \mathrm{mg} / \mathrm{l}$. The minimum value was obtained at the control site in August 2013 wet season while; the maximum value was obtained at EBS in January 2013 dry season. The spatial and temporal variations in the concentrations of Nitrate are presented in Figure 9.

The Nitrate levels of the study area did not show any common trend across the various study stations. The concentration of nitrate varied between 0.15 $2.45 \mathrm{mg} / \mathrm{l}$ in the study period. The highest concentration of nitrate was recorded

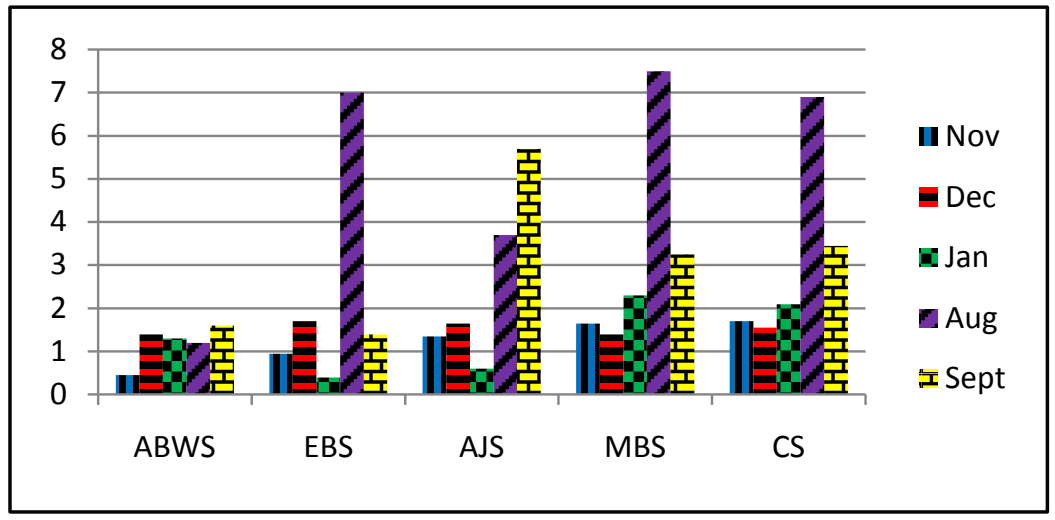

Figure 7. Variation of surface water BOD $(\mathrm{mg} / \mathrm{l})$ in the study stations.

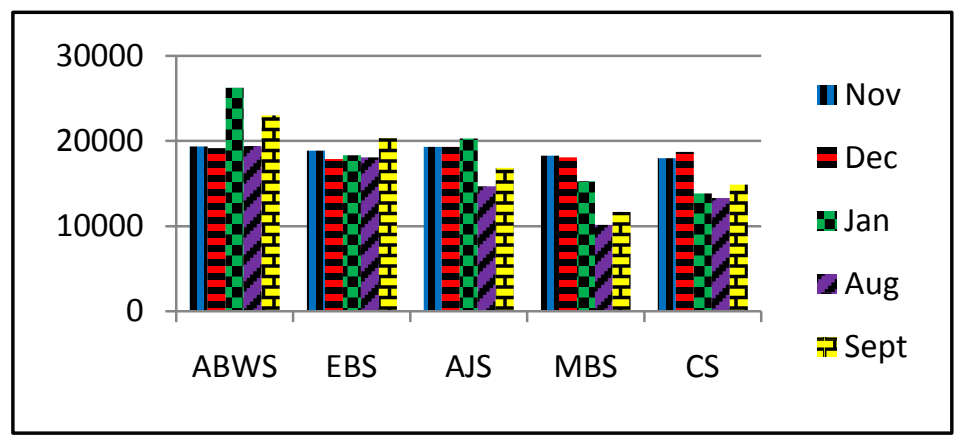

Figure 8. Variations of surface water TDS (mg/l) in study stations.

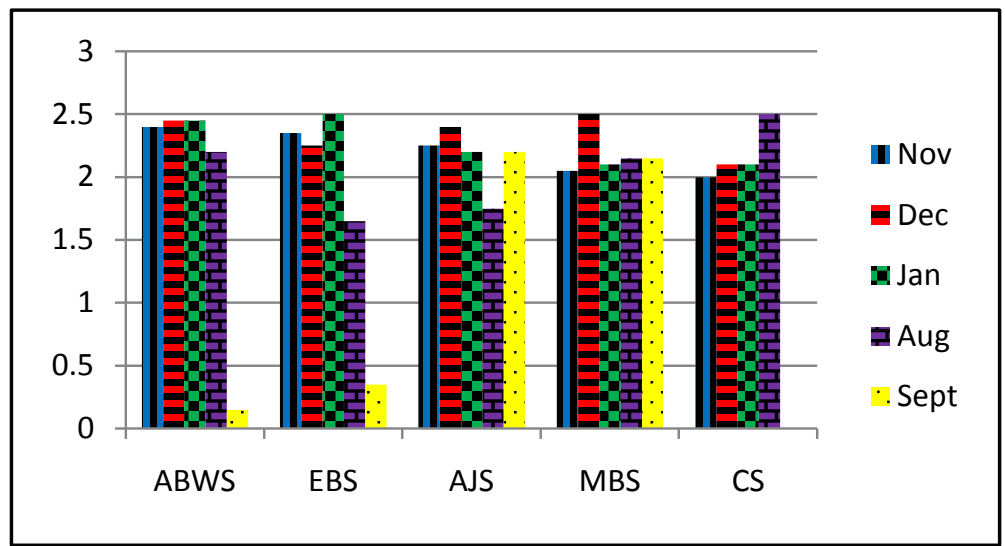

Figure 9. The spatial and temporal variation of surface water nitrate $(\mathrm{mg} / \mathrm{l})$ in study stations. 
at the CS with a value of $2.50 \mathrm{mg} / \mathrm{l}$ in the month of August 2013 wet season.

Concentration of Sulphate $(\mathrm{mg} / \mathrm{l})$ in Surface Water of Sampling Sites

The result indicates that the concentrations of Sulphate ranged from 244.50 $\mathrm{mg} / \mathrm{l}$ at CS in December 2012 dry season, to $581.50 \mathrm{mg} / \mathrm{l}$ at ABWS in December 2012 dry season; with a difference of $337.00 \mathrm{mg} / \mathrm{l}$. The concentration of Sulphate of the surface water was generally high. There was no common trend in the levels of the distribution of the heavy metal across the study sites. The spatial and temporal variations of Sulphate $(\mathrm{mg} / \mathrm{l})$ in the study areas are presented in the Figure 10.

Except for the peak of $581.50 \mathrm{mg} / \mathrm{l}$, at ABWS, the concentrations of Sulphate varied during the period of the study.

\section{Concentration of Ammonia (mg/l) in Surface Water of Sample Sites}

The results indicates that the concentrations of ammonia ranged from $<0.05-$ $0.15(\mathrm{mg} / \mathrm{l})$. There was no common trend in the levels of the distribution of ammonia. The spatial and temporal variations of Ammonia ( $\mathrm{mg} / \mathrm{l})$ in the study areas are presented in the Figure 11.

Copper $(\mathrm{Cu})(\mathrm{mg} / \mathrm{l})$

The lowest value recorded was $<0.01=0.0001(\mathrm{mg} / \mathrm{l})$ while the highest value

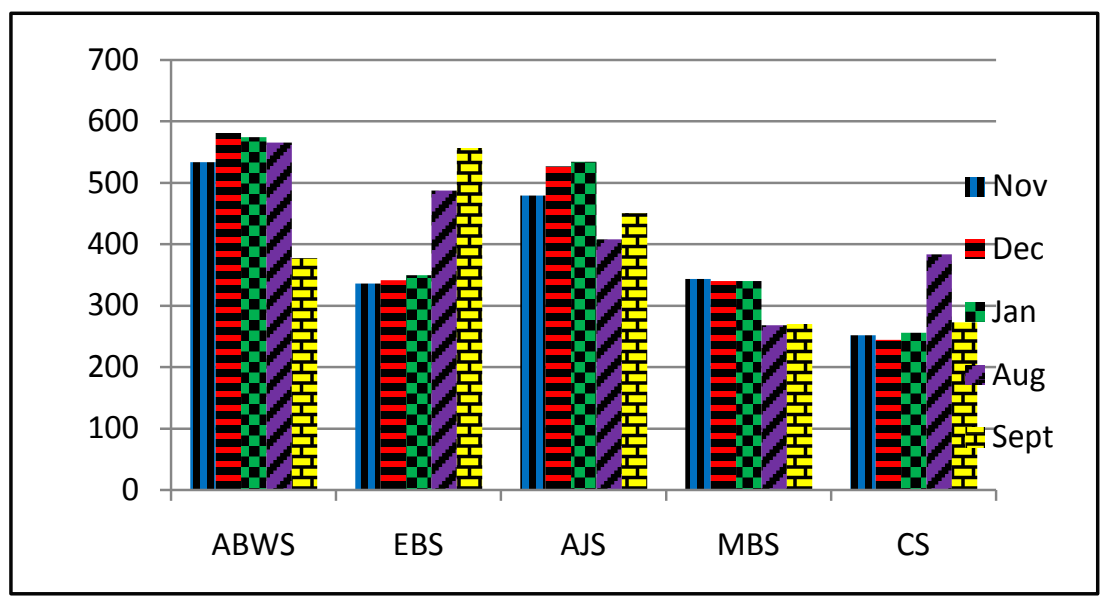

Figure 10. Sulphate concentration $(\mathrm{mg} / \mathrm{l})$ in surface water of the the study stations.

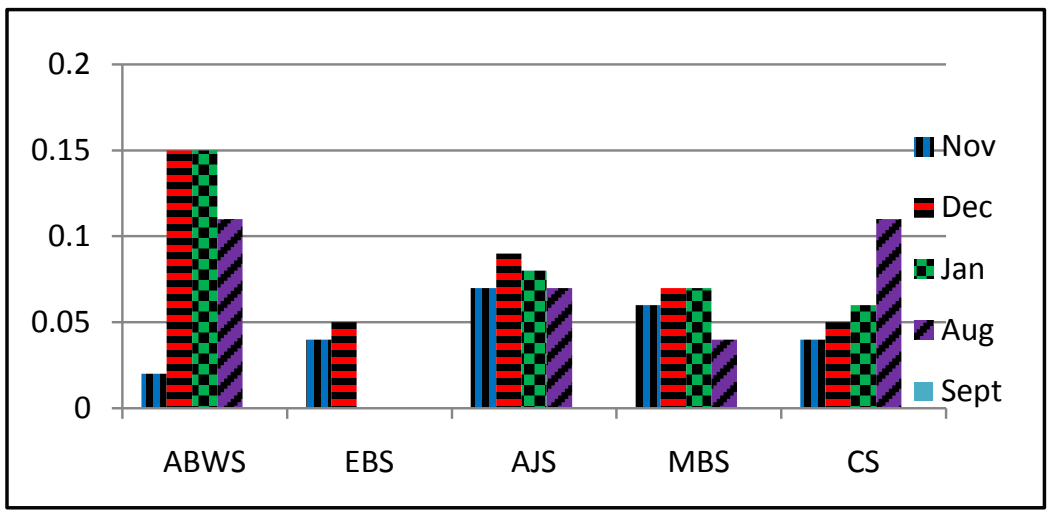

Figure 11. Variations of ammonia $(\mathrm{mg} / \mathrm{l})$ in surface water of the study stations. 
was $0.04(\mathrm{mg} / \mathrm{l})$. The relative values of $\mathrm{Cu}$ did not vary much with the stations and the months. The values were relatively low across the sampling sites and the periods. The lowest and highest values are distributed across the sampling sites and the sampling periods. Variations in the concentrations of $\mathrm{Cu}$ across the study sites did not follow any definite pattern. The spatial and temporal variations of the concentrations of $\mathrm{Cu}$ in the study area are shown in the Figure 12.

\section{Zinc (Zn) Concentration (mg/l) in Surface Water of Sampled Sites}

The concentrations of $\mathrm{Zn}(\mathrm{mg} / \mathrm{l})$ in surface water of the sampling sites range from 0.04 to $0.09(\mathrm{mg} / \mathrm{l})$. The lowest value of $0.044(\mathrm{mg} / \mathrm{l})$ was recorded in the months of December 2012 dry season. The spatial and temporal variation of the concentration of $\mathrm{Zn}$ is presented in the Figure 13.

\section{Concentration of Total Hydrocarbon Content (mg/l)}

The values of the concentrations of THC range from 0.05 to $2.20(\mathrm{mg} / \mathrm{l})$. The lowest value of $0.05(\mathrm{mg} / \mathrm{l})$ was recorded in the months of August 2013 wet season. The spatial and temporal variation of the concentration of THC is presented in the Figure 14.

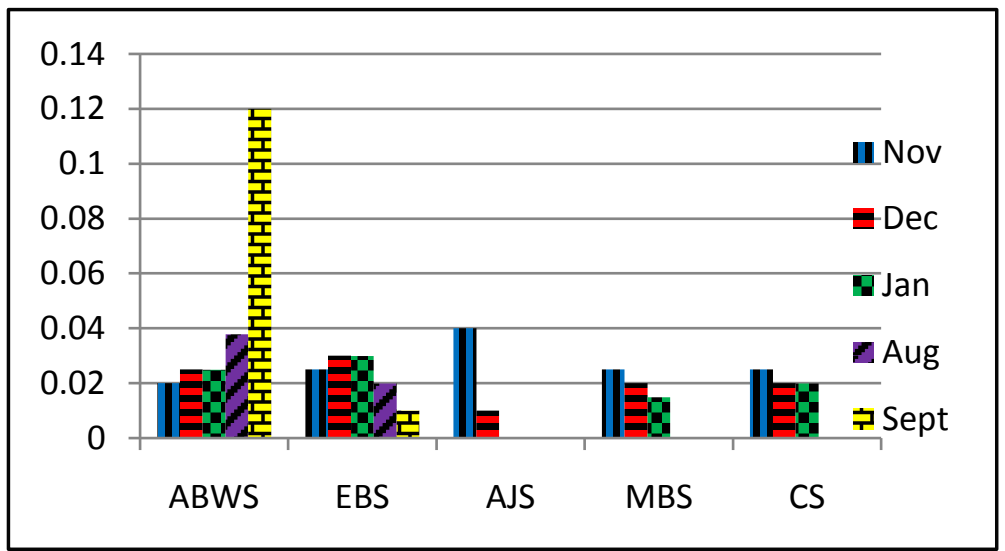

Figure 12. The spatial and temporal variations of the concentrations of copper $(\mathrm{mg} / \mathrm{l})$ in surface water of the study stations.

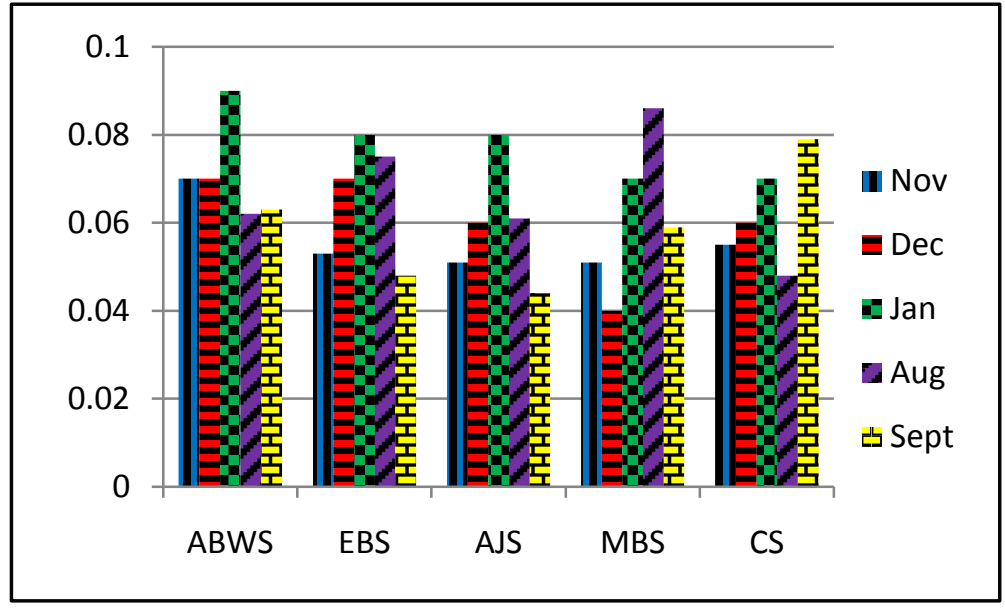

Figure 13. Zinc concentration $(\mathrm{mg} / \mathrm{l})$ in the study stations. 


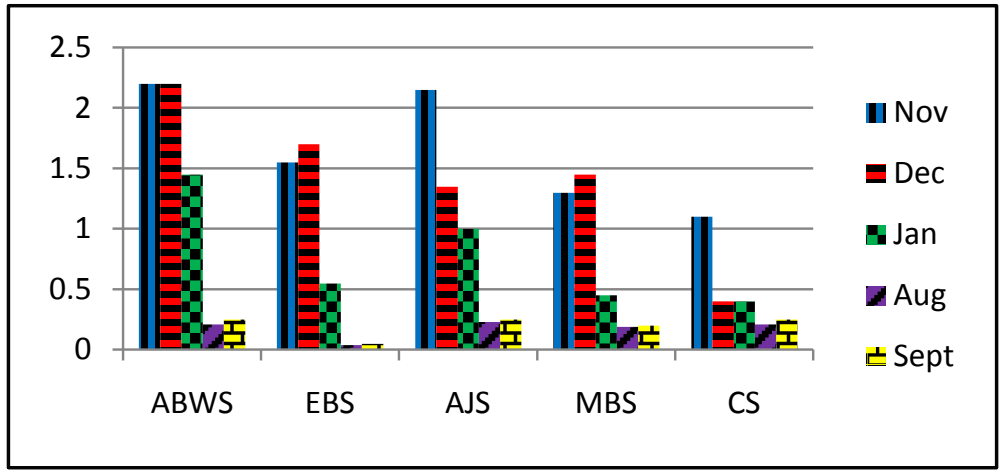

Figure 14. Variations of the mean concentration of total hydrocarbon content (THC) (mg/l) in the study stations.

\section{Discussion}

The $\mathrm{pH}$ values showed that the spatial and temporal variations in the surface water $\mathrm{pH}$ were significant. The range of the $\mathrm{pH}$ values shows that it was tending towards neutral particularly in the study stations in the upper reaches. This suggests evidence of the presence of waste material which is an attribute to human activity. This may also be attributed to water shed and other human activities. However, there are high anthropogenic activities in the settlements along the water fronts in the study area. Most aquatic species adapt to natural condition as certain aquatic species have different tolerance for acidity. Clams, shrimps and snails generally cannot survive with a $\mathrm{pH}$ below 6 [16]. $\mathrm{pH}$ which is an indicator of acidic or alkaline conditions of water status was within level of 7.00. High or low $\mathrm{pH}$ values in a river have been reported to affect aquatic life and alter the toxicity of other pollutant in one form or the other [17].

Though normal biological activity can occur within $\mathrm{pH}$ range restricted to $6.00-8.00$, for natural water, the EEC (1980) guide limit for water is $6.50-8.50$. Thus, the values obtained in the study area fall within this range with the exception of samples collected in August and September, all the other months in all the stations recorded a $\mathrm{pH}$ of $<7.00$ mostly in the dry season. According to [18] and [19], the $\mathrm{pH}$ of brackish water falls within the range 6.50 to 7.40 and 7.48 and 8.89 respectively. In [20], the $\mathrm{pH}$ values ranged from 6.30 to 7.70 for Elechi Creek. The $\mathrm{pH}$ profile in all the study stations falls within the desirable limit for the survival of fishes. A lower $\mathrm{pH}$ value will not support aquatic life [21] and [22] [23] [24].

The surface water temperature profile has a mean value of $29^{\circ} \mathrm{C}$ in the dry season months of November and January and lower during the months of rainy season $\left(27^{\circ} \mathrm{C}-29^{\circ} \mathrm{C}\right)$. Variation of temperature in water bodies attributable to sunlight was reported to occur particularly in estuaries due to their general shallowness, which exposes the water and mudflats to sunlight [20]. [25] reported that temperatures between $26^{\circ} \mathrm{C}$ and $30^{\circ} \mathrm{C}$ are attributed to the insulating effect of increased nutrient load resulting from input of industrial discharge. It therefore, means that the Elechi Creek study area is polluted and constitutes an envi- 
ronmental risk. The temperature obtained $\left(30^{\circ} \mathrm{C}\right)$ according to Delince (1992); $30^{\circ} \mathrm{C}-35^{\circ} \mathrm{C}$ is tolerable to fish, [23] suggested the levels of temperature as $28^{\circ} \mathrm{C}$ $32^{\circ} \mathrm{C}$.

Conductivity which is a method of obtaining an estimate of dissolved solid ranged $3.80-10.0 \mu / \mathrm{cm}$, described as extremely poor in chemicals [26]. [27] recommended the desirable range $100-2000 \mathrm{mS} / \mathrm{cm}$ and acceptable range 30 $5000 \mathrm{mS} / \mathrm{cm}$. The mean electrical conductivity (EC) profile was generally higher at ABWS than other sites. There are several factors that affect the conductivity of a water body. These include concentration or number of ions, mobility of ions, oxidation state (valence) and temperature of the water. Conductivity also increases as result of heavy metal ions released from pollutants such as acid mine drainage. However, the range of EC obtained in the study show marked deviation with the range recorded by [14] [20] at the Elechi Creek which is attributed to series of anthropogenic activities in the study area and seawater influence. The mean value obtained for this study range $19,773 \mu \mathrm{s} / \mathrm{cm}$ to $24,052 \mu \mathrm{s} / \mathrm{cm}$ in dry season and $13,663 \mu \mathrm{s} / \mathrm{cm}$ to $25,325 \mu \mathrm{s} / \mathrm{cm}$ in wet season. These changes, affects the general condition of the water and aquatic lives.

The salinity values recorded at the various sampling sites during the study showed that the values ranged from $7.00(\%)$ to $17.20(\%)$. The values obtained in the study areas are higher than the range [28] reported in Rumueme Creek. Similar low values have been reported by [29] and [30] in the main channel of the Bonny estuary, these coincide with the rainy season, when fresh water discharge was heaviest. Similarly, [31] also reported that low salinity in Bonny tidal basin is influenced by fresh water discharge.

Dissolved oxygen (DO) is a measure of the degree of pollution by organic matter, the destruction of organic substances as well as the self purification capacity of the water body. The DO of Elechi Creek mean values range from 3.23 $\mathrm{mg} / \mathrm{l}$ to $4.65 \mathrm{mg} / \mathrm{l}$ in the dry season and $6.25 \mathrm{mg} / \mathrm{l}$ to $6.53 \mathrm{mg} / \mathrm{l}$ in the wet season at the study area. [21] recommended that fish can die if exposed to less than 0.3 $\mathrm{mg} / \mathrm{l}$ of DO for a long period of time, minimum concentration of $1.0 \mathrm{mg} / \mathrm{l}$. DO is essential to sustain fish for long period and $5.0 \mathrm{mg} \mathrm{L}-1$ are adequate in fishponds. DO in liquid provides a source of oxygen needed for the oxidation of organic matter when the concentration is high and lack of it causes the water body to become dead or devoid of aquatic life [32].

The results of Dissolved Oxygen (DO) concentration of the surface water samples showed that DO concentrations were generally high as values of DO ranged from $2.85-7.45 \mathrm{mg} / \mathrm{l}$ recorded in the study area. The high DO values recorded in the study area can be attributed to the agitation of the surface water within the creek channel due to channel precipitation and run-off discharge especially in the wet season. Similar observation was also made that high DO values were attributed to the extreme turbulent effect of the rains, for which the Niger Delta has been noted for. The relationship between the concentration of organic materials and DO in marine water has been a concern and has been in- 
vestigated. High levels of organic matter are usually associated with low DO concentrations. The fall in DO in November 2012, dry season, at EBS can therefore, be attributed to the organic waste discharged from domestic wastes and others materials discharged from the waterfall settlements. Similarly, the low DO values recorded at AJS in November and December 2012 dry season may be as a result of the utilization of available oxygen by petroleum hydrocarbon discharged into the water surface at the Agip Jetty [33]. The general overall trend/values of dissolved oxygen in all the study sites, when compared to [20] are very low, which clearly suggest a deterioration of the environment and therefore, poses an environmental risk. If a water body is capable of supporting aquatic life, the dissolved oxen standard will be a minimum of $5.00 \mathrm{mg} / \mathrm{l}$ [34].

Biological oxygen demand $\left(\mathrm{BOD}_{5}\right)$ is the commonest used index in water quality management; it represents the amount of oxygen required for the biological decomposition of organic matter under aerobic condition. It is perhaps an expression of how much oxygen is needed for microbes to oxidize a given quantity of organic matter [35]. The mean value of $\left(\mathrm{BOD}_{5}\right)$ in the study stations range from $1.02 \mathrm{mg} / \mathrm{l}$ to $1.78 \mathrm{mg} / \mathrm{l}$ in the dry season and $1.40 \mathrm{mg} / \mathrm{l}$ to 5.38 in the wet seasons the lowest mean value of $\left(\mathrm{BOD}_{5}\right)$ was recorded at the Abonnema wharf station (ABWS) and Elechi beach station (EBS). [36] reported that $\left(\mathrm{BOD}_{5}\right)$ range of 2 to $4 \mathrm{mg} \mathrm{L}-1$ does not show pollution while levels beyond $5 \mathrm{mg} \mathrm{L}-1$ are indicative of serious pollution. According to $[23]$ the $\left(\mathrm{BOD}_{5}\right)$ level between 3.0 $6.0 \mathrm{ppm}$ is optimum for normal activities of fishes; $6.0-12.0 \mathrm{ppm}$ is sublethal to fishes and $>12.0 \mathrm{ppm}$ can usually cause fish kill due to suffocation. $\mathrm{BOD}_{5}$ at $\mathrm{EBS}$, MBS and CS in the wet season show values higher than $5.0 \mathrm{mg} / \mathrm{l}$ which range between $6.90-7.50 \mathrm{mg} / \mathrm{l}$. On the other hands, the Biological Oxygen Demand $\left(\mathrm{BOD}_{5}\right)$ of the surface water samples at these study sites ranged from 0.45 to 7.50 $\mathrm{mg} / \mathrm{l} . \mathrm{BOD}_{5}$ values of 1.35 to $6.90 \mathrm{mg} / \mathrm{l}$ suggesting the "clean water" according to the classification scheme of surface water by Pratt et al. (1971). The higher $\mathrm{BOD}_{5}$ concentrations above $6.20 \mathrm{mg} / \mathrm{l}$ at EBS, MBS and CS suggest some degree of pollution. This trend as discussed above for DO could indicate a level of pollution by organic matter or petroleum hydrocarbons the affected sites (Kinney et al., 1969). The low $\mathrm{BOD}_{5}$ values may have been influenced by the tidal flow of water from the Bonny River which effectively flushes and dilutes oxidizable organic matter out of the study area. This is probably as a result of regular introduction of organic matters into the study area from human and faecal matter on a daily bases. According to [18] and [37], the contamination of water with faeces increases the $\left(\mathrm{BOD}_{5}\right)$ because it contains mainly organic matter making oxygen less available to desirable organisms.

The results also showed low nutrient concentration for example, Nitrate $\left(\mathrm{NO}_{3}\right)$ ranged from $(<0.05$ to $2.80 \mathrm{mg} / \mathrm{l})$. The highest mean levels were recorded at ABWS and MBS. These values are lower than the range of 4.50 to $11.00 \mathrm{mg} / \mathrm{l}$ recorded by [14] in water samples in the upper reaches of the Elechi Creek Bonny estuary. The higher values show a build-up of the Nitrate in the surface water 
especially at MBS and ABWS. The values recorded at these sites can be attributed to the discharge of organic matter from sewage effluence of the waterfront settlement. It could also be explained that the lower mean values of other study sites could be due to relative uptake of nitrate by growing mats of algae which were found covering the exposed mud flats at low tide. The overall low concentration of nitrate in these five areas indicates that they are below the threshold limit of $45.00 \mathrm{mg} / \mathrm{l}$ [38]. Thus, it can be concluded that these areas are not contaminated with nitrate. These values are well below the internationally accepted value of $45.00 \mathrm{mg} / \mathrm{L}$ indicator for nitrate ion contamination and thus this water is not polluted with Nitrate.

Heavy metal concentrations were generally low throughout the stations at Elechi Creek. The low concentration of heavy metal reported in the study stations may be attributed to lack of industrial discharges into the Elechi Creek. It is possible that the abundant suspended matter and high $\mathrm{pH}$ may have effectively scavenged metals through adsorption and precipitation [20].

The results showed that the values obtained for the present studied suggest that the water quality status of Elechi Creek is reasonably influenced by various discharges of effluents into the creek in terms of heavy metal concentrations.

\section{Conclusion}

Change in physico-chemical characteristics of the Elechi Creek could be attributed to the various anthropogenic activities taking place in the study area. These changes are also increasing risk hazard and continued discharge of waste into the Creek without proper management will pose environmental issues in the future. The seasonal variation was such that most of the physico-chemical parameters showed a higher concentration in dry season.

\section{Acknowledgements}

The authors are grateful to the Institute of Geosciences and Space Technology (IGST), Rivers State University of Science and Technology, Port Harcourt, Nigeria for providing the platform for this research.

\section{References}

[1] Ayoade, J.O. (1975) Water Resources and Their Development in Nigeria. Hydrological Science-Bulletien-des Science Hydrologiques, XX, 412.

[2] Chindah, A.C. and Braide, S.A. (2001) Meiofuna Occurance and Distribution in Different Substrate Types of Bonny Brackish Wetland of the Niger Delta. Journal of Applied Sciences and Environmental Management, 5, 33-41.

[3] IPS (1989) Environmental Data Acquisition at Some NNPC Operational Areas. Vol.III Biological Studies. Rivers State University of Science and Technology Port Harcourt Nigeria. Institute of Pollution Studies, SUST/IPS/TR/89/03, 393 p.

[4] IPS (1990) Baseline Ecological Studies of Bonny South (Field) Location. Final Report Rivers State University of Science and Technology Port Harcourt Nigeria. Institute of Pollution Studies, RSUST/IPS/TR/89/02, 288 p. 
[5] IPS (1991b) Baseline Ecological Studies of Bonny South (Field) Location Client: Shell Development Company of Nigeria (1989).

[6] IPS (1992) Environmental Impact Assessment Study of the Nitrogenous Fertilizer Factory Complex, Onne, Rivers State Nigeria. Rivers State University of Science and Technology Port Harcourt Nigeria Institute of Pollution Studies. RSUST/IPS/91/06, $411 \mathrm{p}$.

[7] Onwuteaka, J.N. (1992) The Diversity and Association of Polychaete Fauna in Niger Delta. Ph.D. Thesis, University of Port Harcourt, Port Harcourt.

[8] Ombu, E.I (1987) The Impact of the Okrika Oil Terminal on the Littoral Benthos of the Central Bonny Estuary, Nigeria. Ph.D. Thesis, Rivers State University, Port Harcourt.

[9] Ekweozor, I.K.E., Ombo, E.I. and Ugbome, A.P. (1989) The Effect of Chronic Oil Pollution in the Central Bonny Estuary. The Petroleum Industry and the Nigerian Environment. Proceedings of 1987, 198-207.

[10] Hart, A.I. and Chindah, A.C. (1998) Preliminary Study on the Benthic Microfauna Associated with Different Microhabitants in Mangrove Forest of Bonny Estuary, Niger Delta, Nigeria. Acta Hydrbiol, 40, 9-15.

[11] Chindah, A.C. and Osuamkpe, A. (1994) The Fish Assemblage of the Lower Bonny River, Niger Delta, Nigeria. African Journal of Ecology, 32, 56-65. https://doi.org/10.1111/j.1365-2028.1994.tb00555.x

[12] Rosenberg, R. (1980) Effect of Oxygen Deficiency on Benthic Macrofauna in Fjords. In: Freeland, J., Parmer, D.M. and Levings, C.D., Eds., Fjord Oceanography, Plenum Publishing Corp, New York, 499-514. https://doi.org/10.1007/978-1-4613-3105-6_45

[13] NEDECO (1961) The Waters of the Niger Delta. Netherland Engineering Consult, The Hague, $112 \mathrm{p}$.

[14] Chindah, A.C., Braide, S.A., Amadi, A. and Osuankpe, A. (1993) Investigation into the Epipelic Algal Community of Elechi Creek at Bonny Estuary, Niger Delta, Nigeria. International Journal of Biochemphysics, 2, 119-124.

[15] Wilcox, B.H.P. (1980) Angiosperm Flora of the Mangrove Ecosystem of the Niger Delta. In: Wilcox, B.H.R. and Powell, C.B., Eds., The Mangrove Ecosystem of the Niger Delta, Proceedings of a Workshop, University of Port Harcourt, Port Harcourt, 34-44.

[16] Umejuru, O. (2007) Juvenile Crawfish (Procambarus clarkii) Lc50 Mortality from South Louisiana, Crude/ Peanut and Mineral Oil. Louisiana State University, Baton Rouge.

[17] Morrison, G., Fatoki, O.S., Persson, L. and Ekberg, A. (2001) Assessment of the Impact of Point Source Pollution from the Keiskammahoek Sewage Treatment Plant on the Keiskamma River-pH, Electrical Conductivity, Oxygen Demanding Substance (COD) and Nutrients. Water $S A, 27,475-480$. https://doi.org/10.4314/wsa.v27i4.4960

[18] Imevbore, A.M.A. (1983) The Investigation of Faecal Pollution in the Surface Water of the Niger Delta of Nigeria. Final Report Niger Delta Basin Development Authority, 3, 4-94.

[19] Zhang, J., Yan, J. and Zhang, Z.F. (1995) Nationwide River Chemistry Trend in China: Huanghe and Changjian. Ambio, 24, 275-279.

[20] Obire, O., Tamuno, D.C. and Wemedo, S.A. (2003) Physico-Chemical Quality of Elechi Creek in Port Harcourt. Journal of Applied Sciences \& Environmental Man- 
agement, 7, 43-49. https://doi.org/10.4314/jasem.v7i1.17164

[21] Ekubo, A.A. and Abowei, J.F.N. (2011) Review of Some Water Quality Management Principles Inculture Fisheries. Research Journal of Applied Sciences, Engineering and Technology, 3, 1342-1357.

[22] Santhosh, B. and Singh, N.P. (2007) Guidelines for Water Quality Management for Fish Culture in Tripura, ICAR Research Complex for NEH Region, Tripura Center, Publication No.29.

[23] Bhatnagar, A., Jana, S.N., Garg, S.K., Patra, B.C., Singh, G. and Barman, U.K. (2004) Water Quality Management in Aquaculture. In: Course Manual of Summer School on Development of Sustainable Aquaculture Technology in Fresh and Saline Waters. CCS Haryana Agricultural, Hisar (India), 203-210.

[24] Chapman, P.M., Power, E.A. and Burton Jr., G.A. (1992) Integrative Assessments in Aquatic Ecosystems. In: Burton, G.A. and Leons Jr., M.I., Eds., Sediment Toxicity Assessments, Leons, Chelsea, 313-341.

[25] Alabaster, J.S. and Lloyd, R. (1980) Water Quality for Fresh Fish. Butterworts, London, $283 \mathrm{p}$.

[26] Sikoki, F.D. and Veen, J.V. (2004) Aspects of Water Quality and the Potential for Fish Production of Shiroro Reservoir Nigeria. Living System Sustainable Development, 2, 7 p.

[27] Stone, N.M. and Thomforde, H.K. (2004) Understanding Your Fish Pond Water Analysis Report. Cooperative Extension Program, University of Arkansas at Pine Bluff, Pine Bluff.

[28] Umesi, N., Disiru, C.N.G., Nwogbidi, K.C. and Wokoma, O.A.F. (2013) Effects of Organic Diversity of Littoral Benthos in Sites around the Rumueme Creek in the Upper Bonny Esturay. Journal Leena and Luna International, Oyama, Japan 2013.

[29] Ogamba, E.N., Inyang, I.R. and Seiyahboh, E.I. (2010) A Predictive Model of the Inter Relationship between Physicochemical Parameter and Plankton Productivity in Elechi Creek Complex in the Niger-Delta of Nigeria. African Journal of Applied Zoology \& Environmental Biology, 12.

[30] Daka, E.R. (1990) Studies on the Fouling Community in the upper Bonny Estuary of Southern Nigeria. Master's Thesis, Rivers State University, Port Harcourt.

[31] Dangana, L.B. (1980) Hydrogeomorphological Control of the Mangrove Environment in Parts of Rivers State. In: Wilcox, B.H.R. and Powell, C.B., Eds., The Mangrove Ecosystem of the Niger Delta, University of Port Harcourt, Port Harcourt.

[32] Chukwu, O. (2008) Analysis of Groundwater Pollution from Abattoir Waste in Minna, Nigeria. Research Journal of Diary Science, 2, 74-77.

[33] Kinny, J.P., Buton, D.K. and Schell, D.M. (1969) Kinetic Dissipation and Biodegradation of Crude Oil in Alaska's Cook Inlet. Proceeding Joint Conference on Prevention and Control of Oil Spills APT, Washington DC, 333-340.

[34] Pueblo of Isleta (2002) Surface Water Quality Standards. First Adopted January 24, 1992, Tribal Resolution 92-14, Amended March 18 2002, Tribal Resolution 02-064.

[35] Chukwu, O. (2008) Analysis of Groundwater Pollution from Abbatoir Waste in Minna, Nigeria. Research Journal of Diary Science, 2, 74-77.

[36] Clerk, R.B. (1986) Marine Pollution. Clarandon Press, Oxford, 256 p.

[37] Ekundayo, J.A. (1977) Environmental Consequences of the Pollution of the Lagos Lagon. Bulletin Science Association of Nigeria, 3, 290-299. 
[38] Jagessar, R.C. and Sooknundun, L. (2009) Determination of Nitrate Anion in Waste Water from Nine Selected Areas of Coastal Guyana via a Spectrophotometric Method. http://www.arpapress.com/Volumes/Vol7Issue2/IJRRAS_7_2_15.pdf

Submit or recommend next manuscript to SCIRP and we will provide best service for you:

Accepting pre-submission inquiries through Email, Facebook, LinkedIn, Twitter, etc. A wide selection of journals (inclusive of 9 subjects, more than 200 journals)

Providing 24-hour high-quality service

User-friendly online submission system

Fair and swift peer-review system

Efficient typesetting and proofreading procedure

Display of the result of downloads and visits, as well as the number of cited articles Maximum dissemination of your research work

Submit your manuscript at: http://papersubmission.scirp.org/

Or contact gep@scirp.org 